\title{
Perceptions of adolescents with cancer undergoing palliative care about their illness process
}

\author{
Percepções do adolescente com câncer em cuidados paliativos \\ quanto ao seu processo de adoecimento \\ Percepciones del adolescente con cáncer bajo cuidados \\ paliativos sobre el proceso de su enfermedad
}

\author{
Tuani Magalhães Guimarães ${ }^{a, b}$ \\ Sandra Teixeira de Araújo Pacheco ${ }^{c}$ \\ Michelle Darezzo Rodrigues Nunes ${ }^{c}$ \\ Liliane Faria da Silva ${ }^{d}$
}

\section{How to cite this article:}

Guimarães TM, Pacheco STA, Nunes MDR, Silva LF. Perceptions of adolescents with cancer undergoing palliative care about their illness process. Rev Gaúcha Enferm. 2020;41:e20190223. doi: https://doi. org/10.1590/1983-1447.2020.20190223 aniversidade Federal do Rio de Janeiro (UFRJ), Departamento Materno-infantil. Macaé, Rio de Janeiro, Brasil.

• Universidade Estácio de Sá (UNESA). Niterói, Rio de Janeiro, Brasil.

' Universidade do Estado do Rio de Janeiro (UERJ), Faculdade de Enfermagem, Departamento de Enfermagem Materno-infantil. Rio de Janeiro, Rio de Janeiro, Brasil.

d Universidade Federal Fluminense (UFF). Escola de Enfermagem, Departamento Materno-infantil e Psiquiátrica. Niterói, Rio de Janeiro, Brasil.

\section{ABSTRACT}

Objective: To understand the perception of adolescents with cancer undergoing palliative cares about their illness process. Method: An exploratory and qualitative study, per formed at a federal public hospital specialized in oncology disease in Rio de Janeiro, through interviews with nine adolescents aged 12 to 20 years old, from July to August 2017. Data was submitted to thematic analysis and the theoretical framework was Hildegard Peplau's Theory of Interpersonal Relationships

Results: Three categories emerged: Living the difficult moment of the trajectory of the disease; Feeling the social isolation and that life has stopped; and Overcoming the difficult stage of the disease. They addressed the trajectory of the disease since the diagnosis, with the awakening of feelings of isolation and stagnation of life. Moreover, they highlighted the overcoming power of these adolescents. Final considerations: The study made it possible to know the difficulties experienced during the course of the disease, providing subsidies for the practice of nurses to happen in a sensitive, individualized manner and focused on the individual's need thus enhancing comfort and quality of life.

Keywords: Oncology nursing. Adolescent. Neoplasms. Palliative care

\section{RESUMO}

Objetivo: Compreender as percepções do adolescente com câncer em cuidados paliativos quanto ao seu processo de adoecimento Método: Estudo qualitativo exploratório, realizado em um hospital público federal do Rio de Janeiro, por meio de entrevistas com nove adolescentes de 12 a 20 anos, no período de julho a agosto de 2017. Os dados foram submetidos à análise temática e utilizou-se, como referencial teórico, a Teoria do Relacionamento Interpessoal, de Hildegard Peplau.

Resultados: Emergiram três categorias: Vivendo o momento difícil da trajetória da doença, Sentindo o isolamento social e a vida parar, Superando a fase difícil da doença.

Considerações finais: 0 estudo possibilitou conhecer as dificuldades vividas no decorrer da trajetória da doença, fornecendo subsídios para que a prática do enfermeiro aconteça de formasensível, individualizada e focada na necessidade do indivíduo, aumentando o conforto e a qualidade vida.

Palavras-chave: Enfermagem oncológica. Adolescente. Neoplasias. Cuidados paliativos.

\section{RESUMEN}

Objetivo: comprender la percepción del adolescente con cáncer en cuidados paliativos sobre el proceso de su enfermedad.

Método: estudio exploratorio y cualitativo, realizado en un hospital público federal de Río de Janeiro, a través de entrevistas con nueve adolescentes de 12 a 20 años, entre julio y agosto de 2017. Los datos se sometieron a análisis temáticos y se usó como referencia la Teoría de la relación interpersonal de Hildegard Peplau.

Resultados: Surgieron tres categorías: vivir el difícil momento del curso de la enfermedad; sentir el aislamiento social y cómo se detiene la vida; y Superar la fase difícil de la enfermedad. Estas categorías abordaron el curso de la enfermedad desde su diagnóstico, con el despertar de sentimientos de aislamiento y estancamiento de la vida. Además, subrayaron la fuerza de superación de estos adolescentes.

Consideraciones finales: El estudio permitió conocer las dificultades experimentadas durante el curso de la enfermedad, proporcionando ayudas concretas para que la práctica de las enfermeras suceda de manera sensible, individualizada y centrada en las necesidades del individuo, aumentando la comodidad y la calidad de vida.

Palabras clave: Enfermería oncológica. Adolescente. Neoplasias. Cuidados paliativos. 


\section{口INTRODUCTION}

Cancer comprises a group of diseases that have in common the uncontrolled proliferation of abnormal cells, which invade tissues and organs, and can spread to different parts of the body, causing metastases ${ }^{(1)}$.

When compared to cancer in adults, childhood cancer, ranging from 0-19 years old, is considered rare, corresponding to between $2 \%$ and $3 \%$ of all malignant tumors registered in Brazil. However, it is not less important, as it is among the main causes of death from illness in this population ${ }^{(1)}$.

In Brazil, between 2000 and 2011, the mean incidence rates were 126.65 per million, in the 0 to 14 age group and 139.99 per million for the 0 to 19 age group ${ }^{(2)}$. In the United States of America, adolescents aged 15 to 19 years old were more affected by neoplasms than children between 0 and 14 years old ${ }^{(3)}$.

Adolescence corresponds to a period of life in which biological, cognitive, emotional and social changes occur. Adolescents seek freedom and independence, in a movement to get closer to their peers and distance from their families. In this sense, when faced with the diagnosis of cancer, the natural changes that occur in the process of adolescence are added to feelings of uncertainty and fear ${ }^{(4)}$.

With the diagnosis of cancer, the adolescent begins a process of coping with the disease, in which several therapeutic modalities, such as radiotherapy, chemotherapy, surgery and transplantation are used ${ }^{(1)}$. Throughout this process, a series of changes are imposed on the adolescent in his life and in those around him $^{(5)}$.

Cancer treatment is long and traumatic for those involved in it. Despite the use of ample technological resources for curative purposes, in many cases, when there is a possibility of cure, psychological, social, spiritual and physical suffering may occur during the treatment. Therefore, adolescents diagnosed with cancer can benefit from palliative care along the path of the disease, from diagnosis to the development of the disease ${ }^{(6)}$, remaining as exclusive treatment until the end of life.

Palliative care is an approach whose objective is to improve the quality of life of patients and families who face problems associated with diseases that threaten the continuity of life. Its foundation is the prevention and relief of suffering, through early identification, correct assessment and treatment of pain, and other physical, psychosocial and spiritual problems ${ }^{(7)}$. Care is geared to the patient's needs (symptoms) that result from the evolution of the disease, providing quality survival. Worldwide, only $14 \%$ of all the people in need have access to palliative care ${ }^{(7)}$. This is due to factors such as: unpreparedness in the training of professionals to deal with the impossibility of a cure(8), lack of adequate spaces and/or intended for carrying out palliative care, and the taboo that still exists around the theme.

The institution where the research was carried out has a pediatric palliative care team, which aims to promote the best and most appropriate care measures for children and adolescents out of the possibility of cure, considering the biopsychospiritual aspects that involve the patient and the family.

The role of the nurse with the adolescent who experiences this condition is essential and presupposes comprehensive care involving the biological, psychological, social, economic, spiritual and cultural aspects ${ }^{(8)}$. Thus, in establishing an interpersonal relationship between the patient and the nurse, as proposed by Hildegard Peplau's Theory of Interpersonal Relationship, the nurse can help the patient to develop strategies for better coping with adverse and stressful circumstances that the disease progression and its impossibility to cure cause ${ }^{(9)}$.

A review study conducted in Brazil that sought to produce nursing interventions in palliative care with patients under 18 years old, indicated difficulties in assistance regarding the technique and emotional preparation of nurses when promoting palliative care. The same study also suggested the need for greater investment in training these professionals ${ }^{(10)}$.

Another Brazilian review study ${ }^{(11)}$ that aimed to analyze the scientific evidence about palliative care in pediatric nursing, indicated that only one scientific production covered children and adolescents as participants in the research.

Most publications still focus on family caregivers or the manifestations of symptoms, such as pain ${ }^{(11)}$. Thus, there is a need for studies engaged in giving voice to these subjects who experience such a delicate moment, permeated by various feelings in relation to mutilations and which are not reduced to physical and emotional pain, as they generate the experience of loss and uncertainty of the future ${ }^{(5)}$.

In view of the problems involving nursing care for adolescents in palliative care and the need to give them a voice, the following guiding question is submitted: What are the perceptions of adolescents with cancer related to the disease process? The objective of the present study, on the other hand, sought to understand the perceptions of adolescents with cancer in palliative care regarding their illness process.

\section{METHOD}

The present study is the result of a master's thesis in nursing entitled "Experience and coping of adolescents with cancer out of the possibility of current cure: a study in the light of Peplau"(12). It is configured as an exploratory research 
with a qualitative approach, carried out in the pediatric ward and outpatient clinic of a federal public hospital, specialized in oncology, and that serves people of all ages, in the city of Rio de Janeiro, Brazil.

Regarding the care of children and adolescents, the institution has emergency, outpatient and hospitalization in wards or precaution rooms in oncology and hematology clinics, in addition to an oncology intensive care center.

The adolescents are attended by a multidisciplinary team composed of a doctor, nurse, occupational therapist, psychologist, speech therapist, physiotherapist, social worker and nursing technician. They also have the support of the hospital class teacher, religious and spiritual service and volunteer service that are offered by the hospital.

Nine adolescents, aged 12 to 20 years old, with cancer and in palliative care, participated in the study. The criteria for inclusion were the following: being aware of their condition, be on an outpatient appointment or admitted to the ward.

The time of diagnosis was not a selection criterion, due to the low number of adolescents eligible for the study and with diversified time of diagnosis. In addition, there are cases of highly aggressive and invasive tumors, with virtually impossible cure and whose time of diagnosis may not have an effect for the purposes of selection criteria.

The exclusion criteria included adolescents under treatment for curative purposes, palliative care being monitored only at home, with loss or alteration of consciousness and any other condition that would prevent participation in the interview.

For the selection and recruitment of the possible participants, the authors of the research sought medical and nursing leadership, responsible for the care of adolescents, in order to verify the days of care for possible participants, as well as the list of those who were hospitalized in the ward. After identifying those who met the eligibility criteria, the approach of the participant to the researchers took place through the mediation of a professional from the palliative care team. Thus, the researchers were introduced to the adolescent and family, made the invitation to participate in the research clearly, taking into account the ethical aspects that involve it.

At the clinic, there were five eligible adolescents during the collection period. Everyone was invited to participate in the study, but one refused. In the wards, there were seven eligible; however, five participated in the study, as the other two had a decreased level of consciousness.

For data collection, a questionnaire containing age, gender, education and diagnosis was used to characterize the participants, in addition to a semi-structured interview, with an open question: What is it like for you to be living with an oncological disease in view of the impossibility of cure?

The interviews lasted approximately 20 minutes and were conducted between July and August 2017, individually, and in a reserved and comfortable setting. All the interviews were recorded in audio, transcribed in full and identified by an alphanumeric code, thus guaranteeing the anonymity of the participants. The code was the letter " $A$ ", followed by the Arabic number corresponding to the sequence of execution (A1, A2 and so on). At the end of each interview, the participants and their families received a visit from the psychologist who was part of the research team, and who aimed to support and comfort them, according to the emotional needs that emerged from the interview.

The closure of the fieldwork was based on two criteria. One of them was to reach the total number of adolescent cancer patients in palliative care at the unit during the data collection period, in the outpatient or pediatric ward. The second criterion was that of empirical saturation, achieved through the repetition of data collected ${ }^{(13)}$.

For data analysis, thematic content analysis was used, according the following stages: (1) pre-analysis, with floating reading to know the content of the empirical material generated by the interviews; (2) material exploration phase, when the raw data were transformed into units that represented meanings and then aggregated into the categories; (3) treatment phase and interpretation of results ${ }^{(14)}$.

This research had Hildegard Peplau's Theory of Interpersonal Relationship as a theoretical framework; this theory offers nurses subsidies for a practice based on a therapeutic relationship, with the purpose of stimulating the individual to face the disease and to wish to remain healthy ${ }^{(9)}$.

The study followed the determinations of Resolution No. 466/12, of the National Health Council, being approved by the Ethics Committee in Research with Human Beings of the institution field of study (Opinion No.: 2,181,269), under CAAE 70954217.1.3001.5274. All those responsible for the adolescents signed a Free and Informed Consent Form (FICF) and the adolescents signed the Consent Form (CF).

\section{RESULTS AND DISCUSSION}

Nine adolescents with oncological disease without possibility of cure, aged between 12 and 20 years old took part in the study. Of these, five were male and four, female. Of the total, five were hospitalized and four were being monitored as outpatients. It is noteworthy that those who were hospitalized also underwent outpatient monitoring at the institution where the research was carried out. 
Four participants had incomplete elementary school, followed by one (1) with complete elementary school, two with incomplete high school and two adolescents with complete high school. It is noteworthy that all were away from the school setting.

All the participants were accompanied by their mother. Some were also accompanied by another family member, such as father, aunt, stepfather, and girlfriend. The adolescents lived with their families and sought the hospital for follow-up at the palliative care clinic or in case of hospitalization.

The types of cancer varied between the following: osteosarcoma (4), chondrosarcoma (1), rabioneurosarcoma (1), lymphoma (1), trunk tumor (1) and dermatofibrosarcoma (1). Among the treatments used, nine underwent radiotherapy, eight underwent chemotherapy and four underwent surgical procedures, with two of them suffering limb amputation.

The time of diagnosis of the oncological disease ranged from two months to seven years. Of the total study participants, four had less than a year of diagnosis and five, more than two years. This oscillation in the time of diagnosis suggests realities and understandings that can be different between the participants included in the study. According to a study ${ }^{(15)}$ carried out in the United States, which sought to understand the perspectives of adolescents and young adults diagnosed with advanced cancer, it was seen that over the time of diagnosis and treatment, they became more resilient with regard to the disease condition experienced ${ }^{(15)}$.

Based on the data analysis, three thematic categories emerged, namely: Living the difficult moment of the disease trajectory; Feeling social isolation and life stop; and Overcoming the difficult phase of the disease.

\section{Living the difficult moment of the disease trajectory}

The trajectory of cancer is permeated by several moments of difficulty, which include from the moment of diagnosis of the disease to the various obstacles involved in the treatment. For the adolescents, living with the oncological disease and its uncertain outcome is difficult, complicated or, simply, terrible, as can be seen in the speech of the study participants.

So for me, thereby, at the beginning it was very difficult.

(A2)

In the beginning it was... complicated. (A4)

Ah... the disease itself is terrible, right? Man. (A5)

So, facing the disease, of course, it's difficult. (A1)
Adolescence is a phase marked by the search for freedom and independence, in which one decides what one wants to do, the things with which one has affinity and the desired life projects. This whirlwind of changes generates conflicts and necessary maturation. In this sense, adolescents experience moments of crisis, imbalance and desires; it is also in this period that they seek to build their personality, identifications, autonomy, and their own opinion ${ }^{(16)}$.

However, when faced with the diagnosis of cancer, all the troubles typical of adolescence will be added by the feelings of fear and uncertainty typical of the moment when the adolescent experiences becoming ill(6). In this sense, living with an oncological disease can be characterized as a difficult time for adolescents, as this illness can be understood as a temporary interruption of their dreams and projects, since several changes and adaptations will occur in their lives and their family lives ${ }^{(16)}$.

In this context, when identifying a problem situation, the nurse and the patient, together, must look for a way to solve it. The professional involved should consider the background and individualities of each patient, as each individual must be seen with a unique psychological, spiritual and sociological structure, which will react in a unique way ${ }^{(9)}$.

Among the experiences cited by the adolescents, are the difficulty of living the unknown, of receiving the news of the need for amputation of the limb affected by the disease - and having to, effectively, amputate it -, in addition to having to face the limitations that arose with the progression of the disease, such as the impossibility of locomotion and seeing.

It was very difficult and, like this, we, I didn't know. [...] but I suddenly discovered that I'd have to amputate my foot. (A2)

Difficult... Then, over time, it became even more difficult with the situations that came [...] Oh! When I found out I was going to be amputates, it was very difficult... That is... it was quite complicated to know that I was going to lose a leg, to know that I was going to walk on a crutch. (A4) It is very bad for me to be living this. That is... I got here walking and now l'm not walking like that. It's very bad. [...] And now / don't see it anymore... (the teenager cries). And... it's very bad, very, very bad. This disease, I didn't want anyone to have it. And... just (crying). I... saw it that way when I was here, you know? And now I don't see it anymore... (A6)

With regard to the adolescents'lack of knowledge, highlighted in Peplau's precepts, it is the role of nursing to clarify 
aspects of their illness, the procedures to be developed and the events that happen around them ${ }^{(9)}$.

There is also an adolescent's account of how difficult it is to live with the disease, the "ups and downs" it causes and the loss of friends he came to know during the treatment.

Very difficult. There are many ups and downs... one hour you are well, another you are bad [...] anytime you think you might die, you lose friends you already know here... It's difficult... it's not easy at all. (A7)

In the trajectory of living with the disease, adolescents face the difficulty of facing therapy and its limitations. They express how difficult it is to experience the impossibility of coming and going, of eating whatever they want; they also point out the problems with chemotherapy and radiotherapy, in addition to not being able to be exposed to the sun. They also report the suffering caused by the pain resulting from the treatment and their weakness, which can leave them in bed. They also refer to reactions such as: weakness, vomiting/ nausea, difficulty feeding, lesions in the oral cavity, weight loss, hair loss, fear of acquiring other diseases, in addition to coping with death itself. Such situations end up shaking teenagers, even psychologically.

The oncological disease, in itself is very difficult to live with, because you have chemotherapy, radio (radiotherapy). Ah, there's also that thing: "You can't take a sunbathe, go to the beach, go to the swimming pool." So, for us it's kind of difficult. (A3)

At first, I found everything so easy. But, when I started doing the treatments, that's really difficult. The treatment is very difficult; it wipes you out, man. It makes you weak, throwing up, you throw up everything. I don't eat anything. Now, that last one destroyed my whole mouth. I couldn'teven drink water. Then you lose weight. Hairfalls out. But hair loss is the least. Bad is the sickness that it makes you feeling. Sometimes, you want to eat and you can't. Difficult is the treatment, which is long and complicated, very complicated! [...] These treatments make bad things happen, leave people weak and vulnerable to catching an illness and even end up dying for something totally different. It wasn't even for the cancer. (A7)

Children and adolescents with cancer have several signs and symptoms, such as: pallor, headache, tiredness, joint, bone and general pain, gait change, and lack of appetite, among others ${ }^{(17)}$. The oncological disease impacts on different aspects of life, and it is not different when adhering to the treatments established by the protocols.
Following a strict treatment has many repercussions on the adolescent's life, including social life. One example concerns the specific diet, as food is present in celebrations and in meetings with friends and boyfriends; food has meanings that go beyond the act of eating. However, in order to manage the disease properly, it is essential to control food intake, a condition that is difficult for everyone, especially for the teenager. For the young person, there are great social appeals, such as street food, fast food, soft drinks, sweets and drinks ${ }^{(18)}$.

There are things you cannot eat [...] many people are eating and you can't eat. You'll be in the mood, so you'll want to fight to try to eat that or you'll eat hidden. Of course, you will! You may become sick, but does a teenager want to know that? The teenager is dammed. (A3)

In order to be able to incorporate good eating habits, it is necessary for the adolescent to understand the importance of adequate food for the care of their illness, collaborating with the maintenance of their health. In the Interpersonal Relationship Theory, the nurse, when requesting assistance for a felt need of the adolescent, will be taking the first step towards a dynamic learning experience, in order to help them to be aware of what is happening to them. This phase corresponds to the exploration phase ${ }^{(9)}$.

\section{Feeling social isolation and life stop}

Because it is a chronic disease, cancer imposes restrictions and changes in the adolescent's life. Here, they report their suffering for failing to do basic day-to-day activities with autonomy, stop studying and attending school, experiencing social isolation, in addition to having to adopt a treatment routine.

Well, at the beginning of the disease, for the teenager it's very difficult, because the teenager, normally, he already does everything alone. He's already gone. He likes to do... he studies. He has a social life, being good or bad. He has plans. So, in the beginning you have to stop everything. [...] (A3)

Because you don't go out much, you don't see people and such. (A5)

Because I don't have to do anything. The routine changed. I have to go from there to here by car to do the treatment [...]. (A8)

Upon being diagnosed with cancer, many ruptures occur. The adolescent is forced to separate himself from the activities 
of his social group and from his interests. He realizes that he cannot perform certain tasks because of the limitations imposed by the disease and the treatment ${ }^{(5,18)}$.

The disease also affects the interpersonal relationships of this adolescent, due to the limitations it imposes on the development of his daily activities and his own body image; these changes can lead this adolescent to behave in isolation or even to present a feeling of inferiority ${ }^{(18)}$.

When talking about the interruptions in activities that were practiced before the illness process, the adolescents showed profound suffering in the face of the limitations imposed by the treatment, as is the case of amputation, or by the progression itself.

I played soccer. I played soccer and then it reached my feet, then I had to stop everything. A girl who did everything, out of nowhere, would have to stop her life. (A2) So I had to stop doing what I liked to do. I danced ballet... Sure, for a while. Until my legs took control of themselves again. (A3)

Before doing this surgery (amputation) now that I can't, I can't walk anymore, but I used to go out a lot. I was going to the cinema, I was going to the mall, and I was going to walk with my mother, with my brothers, my girlfriend. (A4)

With the progression of the disease, difficulties arise to carry out activities and, with this, the adolescent is frustrated given the arising impossibilities. The patient who, until then, had lived a "normal" and productive life loses his functions and, in the face of limitations, becomes dependent. This fact can lead the adolescent to an existential crisis, as he is in a phase of life in which he seeks autonomy and independence; with the illness, suddenly, they he himself limited and dependent on basic activities, such as getting up alone. These restrictions can become a nuisance, since exploring everything around you is no longer a possibility ${ }^{(19)}$.

In this regard, it is emphasized that the principles of Peplau's theory can corroborate those of palliative care in pediatrics when focused on the patient and not only on the disease. In these cases, the nurse, as a care therapist, helps the client to achieve a survival that is not limited to the control of signs and symptoms, but that promotes quality of life, contemplating the multiple aspects involved in it: physical, psychosocial and spiritual(9).

The impossibility of attending school and the distancing from the school setting also emerged in the adolescents' statements as one of the factors that contribute to the suffering.
I can't go to school... so... yeah... I have no words to describe

it, you know? (A6)

And the school has changed. I'm not going anymore. (A8)

It is worth mentioning that the school monitoring of the hospitalized child or adolescent is ensured through public policies that aim to guarantee the universality of the right to education for this specific clientele, through this special education modality. Such rights are provided for in the Federal Constitution of 1988, in the Statute of the Child and Adolescent (Estatuto da Criança e do Adolescente, ECA), in the National Special Education Policy, of the National Council for the Rights of Children and Adolescents (Conselho Nacional dos Direitos da Criança e do Adolescente, Conanda), and in the Education Guidelines and Bases Law (Lei de Diretrizes e Bases, LDB) No.9,394/96 (20).

Education is fundamental for the formation of the individual and contributes to the construction of critical capacity and the consolidation of citizenship. The absence of children and adolescents undergoing health treatments, especially when prolonged, as in cases of cancer, can result in feelings of inferiority, triggering a series of considerable losses to their emotional and social development ${ }^{(20)}$.

Thus, in line with Peplau's theory, the need for nurses to seek to stimulate follow-up and school attendance through effective communication with adolescents and their families is reinforced, using health education as a way of preparing them in this process and promoting an environment conducive to the implementation of the hospital class when appropriate ${ }^{(9)}$.

The adolescent explains that he isolates himself because he fears that he will not be accepted and will be discriminated against by the people around him due to the consequences resulting from the treatment of the oncological disease.

So, I stayed there (Casa Ronald) for 1 year and 7 months. And, there, I didn't want to leave. I didn't want to go to the street. I didn't want to go home, return home, because I was afraid of how others would look at me (...) (A4)

Adolescence is a phase permeated by several changes, among them, physical ones. These changes are reflected in changes in self-image. Many adolescents face difficulties with the arrival of pubic and axillary hair, beard and mustache, pimples, changes in the voice and the appearance of breasts. In adolescents with cancer, it is no different ${ }^{(18)}$.

When faced with physical changes resulting from the treatment, the adolescent becomes different from the others. Some side effects of chemotherapeutic drugs lead to 
alopecia, neutropenia (which requires the use of masks), excessive weight loss or weight gain, tumors, scars or even surgeries that lead to amputation. These differences create anguish, can lead the person to isolation and, with this, make him stop his daily and social activities, further impacting his development and future perspectives ${ }^{(18)}$.

This therapeutic relationship developed between nurse and patient consists of a complex care instrument, in that it allows the person to reintegrate and reorganize and allows for a reflection for growing up and for coping with the disease, offering security and help. Such measures enable greater adherence to the proposed treatments and orientation of actions, which also favors the professional to enter the patient's world and be able to share his feelings, understanding his actions and acting with care and love ${ }^{(21)}$.

In this regard, Hildegard Elizabeth Peplau's theory of interpersonal relationships indicates that the focus must be beyond the condition of the health problem, giving importance to the expression of the adolescent's feelings, as well as stimulating coping strategies to help him to better deal with this reality ${ }^{(9)}$.

\section{Overcoming the difficult phase of the disease}

The discovery of cancer and the initiation of treatment are difficult to live with; however, with the passage of time and the adoption of necessary measures and treatments, the adolescents reported adaptation to the disease and the therapeutic routine, as well as the impacts caused on their lives.

I always accepted things very well. [...] Everything has its difficulties, but, for me, it's been very quiet. [...] Everyone accepted the disease well, understand? I went through a difficult phase now, I think about two weeks ago, more or less I was bad at the ICU, but now everything is fine. I am recovering with each passing day. [...] So... I can be happy with... having this disease and taking the necessary care. (A1)

Spending time, you with the people you care about, distracting yourself, you finish until you forget a little about any illness. [...] I've even gotten used to it... These seven years of treatment, with thirteen surgeries I did, so I'm used to it. [...] This is what l adopt to end up forgetting all of that. I know it's difficult, but it's my providence to forget. (A9)

It is clear that living with cancer can be one of the most painful and hard experiences that human beings can experience. Thus, it is important for nurses to intervene at different times, in order to facilitate an adaptive response favorable to the needs of the adolescent, as indicated by Peplau ${ }^{(9)}$.

The participants report that the passage of time and living with other people also undergoing cancer treatment help to overcome the difficult time and to relieve suffering.

But then he got used to it, passed by, saw other people and eased things more. [...] It was passing and then I got used to it, I went home, I started to go out. Then it ended up passing. (A4)

Positive thinking, calm in the face of interventions and tranquility are activated resources that also help this passage through so many mismatches in the routine of the adolescents. The participants try to believe that everything will work out and that they will overcome the disease.

Ah, I always try to stay calm, calm and believe, you know, that everything will get better. Later on, everything will end well. [...] Always believe that everything will work out ahead, and that I will get through it soon. Although it's been a long time like this. (A5)

[...] not thinking... about this disease so much, you know? I don't like it (the cancer disease), so... I don't think about it. I just keep thinking good things, like, my friends, and how it'll be from now on... I'll win... I'll defeat this disease... and I'll leave this place (hospital). No matter whatever it may be. (A6)

Some individual factors can contribute to resilience in adolescents, such as: temperament, learning power, emotional stability, ability to control anger, overcome frustrations quickly, positive self-image, confidence, optimism and positive thinking, ability to solve problems, make decisions, resolve conflicts and manage stress, in addition to good social skills, such as assertiveness, showing concern, empathy, and humor ${ }^{(15)}$.

The adolescent tries to smile to overcome the ruptures that occur facing the illness:

\section{Ah... I always try to smile. Always, I don't know, with a hope, even if it's a little bit of a thread from this, that everything will be fine. [...] And I think that smiling, re- gardless of anything, is the best medicine. (A3)}

We emphasize the importance of coping strategies in the regulation of the positive emotions and increased resilience in the management of cancer-related stress ${ }^{(21)}$.

In this sense, according to Peplau(9), this adaptation process can be favored in the team's interaction with the 
patient in the course of the disease, in order to produce changes that positively influence their health and make them resilient in the face of illness and their impossibility of cure.

\section{GINAL CONSIDERATIONS}

In the light of Peplau's theory, the study made it possible to understand the degree to which living the trajectory of cancer and its consequences was a difficult time for the adolescent, as it implies the interruption of dreams and projects, and changes in social life. Considering the phases of Peplau's interpersonal relationship, it is up to the nurse to value them, promoting ways to favor the adolescents' reflection about what is possible to do. The nurse's practice must include attempts to minimize the suffering experienced, preserving the adolescent's individuality and enabling actions that can lead to comfort and quality of life. Thus, in view of the results of this study, it is highlighted that, in the field of care, it is essential to understand the perception of adolescents with cancer in palliative care. In this way, it is possible to equip the nurse to plan nursing actions that aim to meet the needs of the adolescent and his family in an integral way, in line with the therapeutic objectives of the palliative philosophy. This instrumentation focused on care can be offered during the academic period in undergraduate courses in Nursing, in specializations focused on the theme, in-service education, and short courses, in addition to other forms of training.

The study presented as limitations the fact that it was developed with a small number of participants and in a single hospital that serves this clientele of adolescents with cancer in palliative care.

Considering that the research was carried out in only one institution, it is suggested that new research studies with a thematic approach be developed in other institutions to further deepen the adolescent's coping strategies in palliative care and that use the same theoretical framework or others that have adherence to this specific clientele, which are able to look beyond the disease, such as Peplau's theory, which values the subjectivity of being, in favor of a care that benefits the studied population.

\section{REFERENCES}

1. Instituto Nacional do Câncer Jose Alencar Gomes da Silva (BR). Estimativas/2018: incidência de câncer no Brasil. Rio de Janeiro: INCA; 2018 [citado 2019 jan 24]. Disponível em: http://coleciona-sus.bvs.br/lildbi/docsonline/get. php?id $=1451$
2. Instituto Nacional de Câncer José Alencar Gomes da Silva (BR). Incidência, mortalidade e morbidade hospitalar por câncer em crianças, adolescentes e adultos jovens no Brasil: informações dos registros de câncer e do sistema de mortalidade. Rio de Janeiro: INCA; 2016 [cited 2019 Sep 20]. Available from: http://www1.inca.gov.br/wcm/incidencia/2017/pdf/versa0-completa.pdf

3. Siegel DA, King J, Tai E, Buchanan N, Ajani UA, Li J. Cancer incidence rates and trends among children and adolescents in the United States, 20012009, Pediatrics. 2014;134(4):e945-55. doi: https://doi.org/10.1542/ peds.2013-3926

4. Gomes IP, Lima KA, Rodrigues LV, Lima RAG, Collet N. From diagnosis to survival of pediatric cancer: children's perspective. Texto Contexto Enferm. 2013;22(3):671-9. doi: https://doi.org/10.1590/S0104-07072013000300013

5. Bulla ML, Maia EBS, Ribeiro CA, Borba RIH. The world of the adolescent after being diagnosed with cancer. REME. 2015;19(3):681-8. doi: https://doi. org/10.5935/1415-2762.20150052

6. Silva $A F$, Issi $H B$, Motta MGC, Botene DZA. Palliative care in pediatric oncology: perceptions, expertise and practices from the perspective of the multidisciplinary team. Rev Gaucha Enferm. 2015;36(2):56-62. doi: https:// doi.org/10.1590/1983-1447.2015.02.46299

7. World Health Organization (CH). Palliative care. Geneva: WHO; 2017 [cited 2017 Aug 18]. Available from: http://www.who.int/mediacentre/factsheets/fs402/ en/

8. Guimarães TM, Silva LF, Espírito Santo FH, Moraes JRMM, Pacheco STA. Palliative care in pediatric oncology in nursing education. Rev Gaúcha Enferm. 2017;38(1):e65409. doi: https://doi.org/10.1590/1983-1447.2017.01.65409

9. Peplau H. Relaciones interpersonales en enfermería. Barcelona: Salvat Editores; 1990.

10. Silva e Sousa ADR, Silva LF, Paiva ED. Nursing interventions in palliative care in Pediatric Oncology: an integrative review. Rev Bras Enferm. 2019;72(2):531-40. doi: https://doi.org/10.1590/0034-7167-2018-0121

11. Souza TCF, Correa Júnior AJS, Santana ME, Carvalho JN. Cuidados paliativos pediátricos: análise de estudos de enfermagem. Rev Enferm UFPE on line. 2018 [cited 2019 Jun 05];12(5):1409-22. Available in: https://periodicos.ufpe.br/ revistas/revistaenfermagem/article/view/231901/28901

12. Guimarães TM. Vivência e coping de adolescente com doença oncológica fora de possibilidade de cura atual: um estudo à luz de Peplau [dissertação]. Rio de Janeiro (RJ): Faculdade de Enfermagem, Universidade do Estado do Rio de Janeiro; 2018.

13. Fontanella BJB, Magdaleno Jr R. Saturação teórica em pesquisas qualitativas: contribuições psicanalíticas. Psicol Estud. 2012; [citado 2018 ago 25];17(1):6371. Disponível em: https://www.redalyc.org/articulo.oa?id=287123554008

14. Bardin, L. Análise de conteúdo. São Paulo: Edições 70; 2011.

15. Gray MF, Ludman EJ, Beatty T, Rosenberg AR, Wernli KJ. Balancing hope and risk among adolescent and young adult cancer patients with late-stage cancer: a qualitative interview study. J Adolesc Young Adult Oncol. 2018;7(6):673-80. doi: https://doi.org/10.1089/jaya0.2018.0048

16. Nunes MDR, Nascimento LC, Fernandes AM, Batalha L, Campos C, Gonçalves A, et al. Pain, sleep patterns, and HRQOL in pediatric patients with cancer. Eur J Cancer Care. 2019;28(4):e13029. doi: https://doi.org/10.1111/ecc. 13029

17. Ministério da Saúde (BR), Instituto Nacional de Câncer. Câncer infanto-juvenil. Rio de Janeiro: INCA; 2017 [cited 2017 Jun 18]. Available from: http://www. inca.gov.br/dia-mundial-do-cancer/cancer-infantojuvenil.asp 
18. Silva LLT, Vecchia BP, Braga PP. Adolescer em pessoas com doenças crônicas: uma análise compreensiva. Rev Baiana Enferm. 2016;30(2):1-9. doi: https:// doi.org/10.18471/rbe.v30i2.14281

19. Matos MR, Muniz RM, Viegas AC, Przylynski DS, Holz AW. Meaning of home care and the moments experienced by oncologic patients in palliative care. Rev Eletr Enf. 2016;18:e1179. doi: https://doi.org/10.5216/ree.v18.35061
20. Silva VMG, Da Hora SS. Impacts of cancer on the school life of children and adolescents: the importance of hospital class. Rev Bras Cancerol. 2018;64(3):4014. doi: https://doi.org/10.32635/2176-9745.RBC.2018v64n3.47

21. Murphy LK1, Bettis AH, Gruhn MA, Gerhardt CA, Vannatta K, Compas BE. Resilience in adolescents with cancer: association of coping with positive and negative affect. J Dev Behav Pediatr. 2017;38(8):646-53. doi: https://doi. org/10.1097/DBP.0000000000000484

\section{- Corresponding author:}

Liliane Faria da Silva

E-mail: lili.05@hotmail.com

\section{Associate editor:}

Wiliam Wegner

\section{Editor-in-chief:}

Maria da Graça Oliveira Crossetti 